\title{
Businessman or Host? Individual Differences between Entrepreneurs and Small Business Owners in the Hospitality Industry
}

Stephanie L. Wagener, Marjan J. Gorgievski, and Serge A. Rijsdijk

\begin{tabular}{|l|l|}
\hline \multicolumn{2}{|l|}{ ERIM REPORT SERIES RESEARCH IN MANAGEMENT } \\
\hline ERIM Report Series reference number & ERS-2008-073-ORG \\
\hline Publication & November 2008 \\
\hline Number of pages & 34 \\
\hline Persistent paper URL & http://hdl.handle.net/1765/13832 \\
\hline Email address corresponding author & srijsdijk@rsm.nl \\
\hline Address & Erasmus Research Institute of Management (ERIM) \\
& RSM Erasmus University / Erasmus School of Economics \\
& Erasmus Universiteit Rotterdam \\
& P.O.Box 1738 \\
& 3000 DR Rotterdam, The Netherlands \\
& Phone: + 31104081182 \\
& Fax: $\quad+31104089640$ \\
& Email: info@erim.eur.nl \\
& Internet: $\quad$ www.erim.eur.nl \\
\hline
\end{tabular}

Bibliographic data and classifications of all the ERIM reports are also available on the ERIM website: www.erim.eur.nl 


\section{ERASMUS RESEARCH INSTITUTE OF MANAGEMENT}

\section{REPORT SERIES}

\section{RESEARCH IN MANAGEMENT}

\begin{tabular}{|l|l|}
\hline ABSTRACT AND KEYWORDS \\
\hline Abstract & $\begin{array}{l}\text { Prior research has identified individual characteristics that distinguish business owners from non- } \\
\text { business owners. We tested our contention that not every successful business owner can be } \\
\text { characterized by such typical "entrepreneurial" characteristics. Multiple Analysis of Variance } \\
\text { (MANOVA) on a unique dataset of 194 business owners in the hospitality industry revealed that } \\
\text { several individual characteristics discriminated between entrepreneurs and small business } \\
\text { owners. Entrepreneurs possessed higher levels of independence, tolerance of ambiguity, risk- } \\
\text { taking propensity, innovativeness, and leadership qualities, but not of market orientation and } \\
\text { self-efficacy. We conclude that "entrepreneurial" characteristics identified in the literature may be } \\
\text { useful predicting a specific type of business ownership. However, other criteria need to be } \\
\text { developed in order to describe other groups of business owners operating in the service } \\
\text { industry. }\end{array}$ \\
\hline Free Keywords & $\begin{array}{l}\text { business success, entrepreneurship, small business owners, job performance, personality } \\
\text { characteristics }\end{array}$ \\
\hline Availability & $\begin{array}{l}\text { The ERIM Report Series is distributed through the following platforms: } \\
\text { Academic Repository at Erasmus University (DEAR), DEAR ERIM Series Portal } \\
\text { Social Science Research Network (SSRN), SSRN ERIM Series Webpage } \\
\text { Research Papers in Economics (REPEC), REPEC ERIM Series Webpage }\end{array}$ \\
\hline Classifications & $\begin{array}{l}\text { The electronic versions of the papers in the ERIM report Series contain bibliographic metadata } \\
\text { by the following classification systems: } \\
\text { Library of Congress Classification, (LCC) LCC Webpage } \\
\text { Journal of Economic Literature, (JEL), JEL Webpage } \\
\text { ACM Computing Classification System CCS Webpage } \\
\text { Inspec Classification scheme (ICS), ICS Webpage }\end{array}$ \\
\hline
\end{tabular}


Running head: Businessman or host?

\title{
Businessman Or Host? Individual Differences Between Entrepreneurs And Small Business Owners In The Hospitality Industry
}

\author{
Stephanie L. Wagener \\ Erasmus University Rotterdam \\ Marjan J. Gorgievski \\ Erasmus University Rotterdam \\ Serge A. Rijsdijk \\ Rotterdam School of Management
}

This is a preprint of an article submitted for consideration in the Service Industries Journal @ 200? Taylor \& Francis.

Correspondence concerning this article should be addressed to Dr. Marjan J.

Gorgievski, Erasmus University Rotterdam, Department of Psychology, Room T13-03, P.O. Box 1738, NL-3000 DR Rotterdam, The Netherlands.

Email: gorgievski@fsw.eur.nl. 


\title{
Businessman Or Host? Individual Differences Between Entrepreneurs And Small Business Owners In The Hospitality Industry
}

\begin{abstract}
Prior research has identified individual characteristics that distinguish business owners from non-business owners. We tested our contention that not every successful business owner can be characterized by such typical "entrepreneurial" characteristics. Multiple Analysis of Variance (MANOVA) on a unique dataset of 194 business owners in the hospitality industry revealed that several individual characteristics discriminated between entrepreneurs and small business owners. Entrepreneurs possessed higher levels of independence, tolerance of ambiguity, risk-taking propensity, innovativeness, and leadership qualities, but not of market orientation and self-efficacy. We conclude that "entrepreneurial" characteristics identified in the literature may be useful predicting a specific type of business ownership. However, other criteria need to be developed in order to describe other groups of business owners operating in the service industry.
\end{abstract}

Key words: business success, entrepreneurship, small business owners, job performance, personality characteristics 


\section{Businessman Or Host? Individual Differences Between Entrepreneurs And Small Business Owners In The Hospitality Industry}

The importance of small and medium sized enterprises for today's economy through, for example, job creation and economic growth has often been highlighted. The service sector employs the majority of employees in Western countries and, as such, entrepreneurship within this sector receives growing attention (see e.g., Dobon and Soriano, 2008). Many research endeavors have aimed at identifying factors that explain how business owners make their fundamental contribution to economic development (see e.g., Altinay \& Altinay, 2006; Bryson, Keeble \& Wood, 1993). Despite the important insights gained from these studies little, however, is known about possible different types of business owners within the service industry. The need to differentiate between different types of business owners when studying business success is an important issue, because different groups may strive for different goals and thereby depend on different success factors. Recent investigations showed, for example, that business owners who are guided by personal values of power and achievement, find business growth a more important success criterion, and hence also have larger businesses, than business owners who value power and achievement less (Gorgievski \& Zarafshani, 2008). In contrast, business owners with other value orientations, such as benevolence, valued other success criteria more, such as having satisfied customers and employees, or social and environmentally friendly enterprising. Not distinguishing between such groups may foreclose an effective capturing of the factors that enhance the performance of each of these groups.

The present study aims to differentiate between entrepreneurial business owners and small business owners in the hospitality industry. Broadly, these two groups can be identified in any taxonomy of business owners and their business ventures based on 
goals and activities. One example is Smith and Miner's (1983) distinction between the "opportunistic" entrepreneur and the "craftsman" entrepreneur. The opportunistic entrepreneur has a managerial focus, has a broad business strategy including innovation of products and services, marketing methods, distribution channels, etc., has more professional relationships with clients and employees, delegates responsibility to the point where the organization can run itself, is growth oriented, and engages in long term planning. The craftsman entrepreneur has a business strategy restricted to price, quality and reputation, develops business contacts with clients and employees on a personal basis, does not delegate much authority and responsibility in order to be able to build the organization, and is mainly interested in maintaining the status quo concerning production methods, type of services or goods. Another classic taxonomy is Carland, Hoy, Boulton and Carland's (1984) distinction between on the one hand entrepreneurial ventures, which would be characterized by innovative strategic practices and profitability and growth as principle goals versus small businesses defined as 'any business that is independently owned and operated, not dominant in its field, that does not engage in any new marketing or innovative practices' (Carland et al., 1984). More recently, Kunkel (2001) identified "High Growth-Potential" new venturing, which could be either need driven or technology driven, from "Low GrowthPotential" new venturing, which could, for example, be "Income Substituting" with the intent to generate an income for themselves and their family comparable to what other people can earn working for someone else. We assert that predictors of business owners' success identified in prior research can be expected to differentiate between entrepreneurs and small business owners that are active in the hospitality industry.

\section{Traditional discriminators between business owners and non-business owners}

In the literature, two major individual difference approaches to describing 
business owners can be distinguished: a personality and a competency approach. The personality approach focuses on relatively permanent traits, dispositions, or characteristics within the individual that give some measure of consistency to that person's behaviour (Feist \& Feist, 2006). More recently, the focus in entrepreneurship literature has shifted towards a broader assemblage branded entrepreneurial competencies, which also include knowledge, skills, and abilities that assist people in their efforts to exploit opportunities and establish successful ventures, and that are generally believed to be more attainable, variable and subject to cursory change than personality characteristics (Baron \& Markman, 2003; Baum, Frese \& Baron, 2007).

In the next section we will give an overview of several personal characteristics and competencies that have been found predictive of business ownership in prior research (Rauch \& Frese, 2007a; 2007b), but which we expect to distinguish entrepreneurs from other small business owners. Reason is that these characteristics have been theorized to help people perform tasks that are more typical for entrepreneurs (e.g, Mazzarol \& Reboud, 2006; Tang, Tang \& Lohrke, 2008), but might to a much lesser extent be part of the jobs of other small business owners (e.g. the craftsmanentrepreneur, Carland et al, 1984; or the income- substituting low-growth potential business owner, Kunkel, 2001). We focused on seven characteristics and competencies that would enable people to deal with typical entrepreneurial tasks. Six of these tasks related to innovativeness and seeking new opportunities, namely independence, tolerance of ambiguity, risk taking propensity, innovativeness, self-efficacy, and market orientation. The last competency is transformational leadership skills, related to the task of delegating responsibilities.

\section{Independence}

Both entrepreneurs and small business owners refer to being independent as a 
primary motive to set up their own business (Hisrich, 1990; Kuratko, Hornsby \& Naffziger, 1997). Independence entails taking responsibility for one's own judgement as opposed to following the assertion of others (Shane, Locke \& Collins, 2003). The concept of independence is closely linked to autonomy, which refers to the independent action of an individual in bringing forth an idea or a vision and carrying it through to completion (Lumpkin \& Dess, 1996).

The current study will investigate whether entrepreneurs and small business owners differ in their propensity for independence. Many investigators have observed that the entrepreneurial role, related to creating and innovating, necessitates independence. Independence is a frequently cited characteristic of entrepreneurs (Carton, Hofer \& Meeks, 1998; Utch, Rauch, Rothfuss \& Frese, 1999; Cromie, 2000; Pines, Sadeh, Dvir \& Yafe-Yanai, 2002; Lim, Ribeiro \& Lee, 2008). In addition, firm founders scored significantly higher than the general population on personality measures of independence (Aldridge, 1997; Hornaday \& Aboud, 1971). Being independent allows these entrepreneurs to take potentially unpopular decisions, which is sometimes necessary under the unstable circumstances in which they often operate. In contrast, small business owners operate in more stable environments characterized by more constraining properties. People with low independence may find such environments more desirable than unstable, novel environments. Conform the attraction-selection-attrition mechanisms proposed by Schneider, Goldstein and Smith (1995), people scoring low on independence may therefore select themselves into small businesses, and leave the field when they face major changes. Based on these assumptions, the hypothesis concerning independence is stated as follows:

$H_{1}$ : Entrepreneurs show more independence than small business owners. 


\section{Risk-taking Propensity}

Risk and uncertainty are part of the entrepreneurial world (Cromie, 2000). Therefore many scholars have theorized that entrepreneurs need to have higher risk-taking propensity than other people (Schumpeter, 1934; Tang et al., 2008). Risk-taking propensity can be effectively conceptualized as an individuals' orientation toward taking chances in a decision-making scenario. Risk-taking propensity is often considered one of the main characteristics of enterprising individuals (Ahmed, 1985; Brandstätter, 1997; Carton et al., 1998; Cromie, 2000; Pines et al., 2002; White, Thornhill \& Hampson, 2006; Lim, Ribeiro \& Lee, 2008). However, empirical research comparing firm-owners to managers or the general population showed no difference in risk-taking propensity (Shane et al., 2003). Moreover, some studies even suggest a negative relationship. Duchesneau and Gartner (1990) indicate that successful entrepreneurs seek to reduce risks. Rauch and Frese (2000) found that high risk-taking is negatively associated with business success. The lack of consensus in the literature regarding the risk-taking propensities of entrepreneurs might have emerged because of the various definitions of risk taking employed in research on entrepreneurship. In some studies, risk refers specifically to the probability of loss or negative outcome (Lumpkin \& Dess, 1996). Logically, studies in which this definition is used will obtain different results than studies that conceptualize risk-taking propensity as taking calculated risks in order to obtain possible, identifiable gains. This is because the risks people take when making decisions, depends on whether they frame the situation as one of possible loss, versus one of possible gains. People will try to minimize risk when they expect gains, but maximize risk when they expect loss.

This study will examine if risk-taking propensity, defined as calculated risks in order to obtain potential advantage, is a characteristic on which entrepreneurs and small 
business owners can be distinguished. Carland et al. (1984) suggested that entrepreneurs might entail extended risks relative to the small business owner. Stewart, Watson, Carland and Carland (1998) confirmed this assertion showing that small business owners were less risk-oriented than entrepreneurs. Based on this information, the following hypothesis regarding risk-taking propensity is postulated:

$\mathrm{H}_{2}$ : Entrepreneurs display higher risk-taking propensity than small business owners.

\section{Tolerance of Ambiguity}

An ambiguous situation is a situation that cannot be adequately structured or categorized by an individual, because it lacks clarity and sufficient cues (Begley \& Boyd, 1987b). Ambiguity may emanate from novelty, complexity, or insolubility. Tolerance of ambiguity can be defined as the tendency to perceive ambiguous situations as neutral or even desirable, and intolerance of ambiguity as the tendency to perceive such situations as threatening (Budner, 1962). MacDonald (1970) is even less circumspect claiming that persons with high tolerance of ambiguity deliberately seek unstructured situations.

Many entrepreneurial decisions will involve ambiguity because decisions result in actions that are innovative and original. Scheré (1982) referred to the role of entrepreneur as "an ambiguity-bearing role". He found that entrepreneurs display more ambiguity tolerance than managers. Begley and Boyd (1987a) also found that firm founders scored significantly higher on tolerance of ambiguity than did managers. In a more recent study, Koh (1996) confirmed that tolerance of ambiguity is one of the essential features differentiating entrepreneurs from people who are not entrepreneurially inclined. However, several studies did not replicate these findings (Shane et al., 2003). Babb and Babb (1992) and Begley (1995) found no significant 
difference in tolerance of ambiguity between founders and business owners who had acquired an already existing firm, or founders and managers. Regarding the difference between entrepreneurs and small business owners concerning growth and innovation, we expect that entrepreneurs will face more ambiguous and uncertain situations than small business owners (Timmons, 1990). Small business owners can be expected to face more stable and well-known situations, and people who are less tolerant for ambiguity may more likely seek such environments (cf. Schneider et al., 1995). Hypothesis 3 is therefore:

$H_{3}$ : Entrepreneurs manifest higher tolerance of ambiguity than small business owners.

\section{Self-efficacy}

Self-efficacy is the belief in one's ability to muster and implement the necessary personal resources, skills, and competencies to attain a certain level of achievement on a given task (Bandura, 1997). It is a personality characteristic that refers to an individual's cognitive estimate of his or her capabilities to exercise control over events in their lives. Recently, there has been an increasing emphasis on the role of selfefficacy in entrepreneurship (see e.g., Lim, Ribeiro \& Lee, 2008). Markman and Baron (2003) assert that entrepreneurs with high self-efficacy will outperform entrepreneurs with lower levels of self-efficacy because the former believe that their actions will lead to attainable outcomes. The higher confidence of entrepreneurs encourages them to take action before it makes complete sense. This entails risks, but also leads to opportunities that will most likely be gone by the time more complete data becomes available (Busenitz \& Barney, 1997). Cromie (2000) approaches the relationship between entrepreneurship and self-confidence in a different way by suggesting that selfconfidence is an outcome rather than a determinant of entrepreneurship. 
Chen, Greene \& Crick (1998) provided evidence that entrepreneurial selfefficacy, defined as an individual's confidence in his or her ability to successfully perform entrepreneurial roles and tasks, was positively related to the intention to start a new business. In addition, the degree of entrepreneurial self-efficacy in founders and non-founders of enterprises differed significantly (Zhao, Seibert \& Hills, 2005). Selfefficacy and self-confidence are often associated with venture growth and entrepreneurial orientation (Koh, 1996; Utsch et al., 1999; Pines et al., 2002; Shane et al., 2003; Baum \& Locke, 2004). Until now, no studies have compared entrepreneurs to small business owners concerning their self-efficacy. However, based on the information regarding entrepreneurs and small business owners in general, the following hypothesis regarding self-efficacy is postulated:

$H_{4}$ : Entrepreneurs demonstrate higher self-efficacy than small business owners.

\section{Innovativeness}

Nearly all definitions of entrepreneurship entail innovativeness and creative processes. Entrepreneurship is a fundamentally creative act (Timmons, 1990). Enterprising individuals develop new ideas and concepts, spot opportunities or combine existing ideas and resources in new ways to create additional value (Cromie, 2000). Innovation refers to the tendency to engage in and support new ideas, novelty, experimentation, and creative processes that may result in new products, services, or technological processes (Lumpkin \& Dess, 1996). These behaviors are indicative of a level of creative ability possessed by entrepreneurs, as manifested by their strategic behavior. Both creativity and innovation are personality traits that are inherent to the role of entrepreneurship (Drucker, 1985).

Empirical research reveals that entrepreneurs display higher creativity than nonentrepreneurs (Carton et al., 1998; Utsch et al., 1999; Cromie, 2000; Pines et al., 2002; 
Ward, 2004; Bartram, 2005). Lumpkin and Dess (1996) investigated the nature of the entrepreneurial orientation construct and found innovativeness to be one of the five chore dimensions. Timmons (1990) asserts that creativity and innovativeness are desirable but not easily acquirable characteristics that can contribute to entrepreneurial success. Innovativeness is generally considered a prerequisite for significant business growth (Mazzarol \& Reboud, 2006). By definition, entrepreneurs would show more innovation than small business owners (Carland, Hoy \& Carland, 1988). Research on creativity and innovativeness in small business owners is scarce. The following hypothesis regarding innovativeness is formulated:

$H_{5}$ : Entrepreneurs exhibit a higher degree of innovative abilities than small business owners.

\section{Market Orientation}

Market orientation is closely related to entrepreneurship and has emerged as a critical topic in entrepreneurial opportunities. A firm characterized as market oriented has an understanding of potential customer needs, provides superior customer value and responds to changing customer needs and competitor activities in order to exploit opportunities and circumvent threats (Morgan \& Strong, 1998). Markman and Baron (2003; also Mazzarol \& Reboud, 2006) assert that successful entrepreneurs have the insight to match technical discoveries with buyer's needs and the stamina, knowledge, skills, and abilities to fruitfully deploy their offerings in the market. According to Venkataraman (1997), entrepreneurship involves the nexus of two phenomena: the presence of lucrative opportunities and the presence of enterprising individuals. To fully exploit the lucrative opportunities, this enterprising individual must possess a certain degree of market orientation.

In an investigation comparing successful and unsuccessful entrepreneurs, 
Duchesneau and Gartner (1990) found that successful entrepreneurs undertake more market research and are more market oriented. In a study of Altink and Born (1993) market orientation was ranked the second most important requirement for the general role of entrepreneur. Kaish and Gilad (1991) state that entrepreneurs display a higher level of alertness by constantly searching for opportunities and ideas. This entrepreneurial alertness is a form of market orientation leading to entrepreneurial success. Because compared to small business owners, entrepreneurs have a stronger orientation toward growth, profit, and innovation we assert the following hypothesis:

$H_{6}:$ Entrepreneurs reveal higher levels of market orientation than small business owners.

\section{Leadership Qualities}

Leadership can be defined as the ability of an individual to influence, motivate, and enable others to contribute toward the effectiveness and success of the organizations of which they are members (House, 2004). Organizationally, leadership is expected to directly impact the effectiveness of costs, revenue generation, service, market value, motivation, and sustainability and involves directing, guiding, and supporting employees in order to accomplish their task achievement (Smid \& Van der Woude, 2005). Leadership is a competency because it can be trained and developed.

Hornaday and Aboud (1971) discovered that compared to men in general, entrepreneurs score significantly higher on leadership scales. Lim, Ribeiro \& Lee (2008) showed that leadership has a positive impact on the performance of entrepreneurial firms in the service sector. Timmons (1990) explains that leadership is one of the six most dominant themes regarding successful entrepreneurship. Since entrepreneurs have a higher growth orientation, a stronger leadership position may be necessary for entrepreneurs in order to obtain the growth and profits they aspire. In 
contrast, small business owners may have a looser and less hierarchical relationship with their personnel (Smith \& Miner, 1983). They may do even if they need to do much of the labor themselves. However, lack of leadership skills can be expected to hinder them in attaining growth. Therefore we assume that entrepreneurs will have stronger leadership qualities than small business owners:

$H_{7}$ : Entrepreneurs will possess more leadership competencies than small business owners.

\section{Method}

\section{Sample and Procedure}

Our sample consisted of people owning a venture in the hospitality-industry such as a restaurant, bar, or hotel. Sixteen subject matter experts had identified two equal groups of entrepreneurs and hosts. The subject matter experts were establishment-directors of a large hospitality beverage supplier in The Netherlands, who were familiar with the enterprises and capable of appraising the entrepreneurial achievement of the venture. Each director independently managed one of sixteen regions, serving between 1000 to 5000 entrepreneurs per region. They were knowledgeable and experienced in the field of entrepreneurship in the hospitality branch. Moreover, region-directors have relatively close relationships with their customers. In addition to providing the beverage-supply of the business owners, they also advised them about management, financing and other aspects of entrepreneurship and have a good overview of business owners who are successful and those who might need extra advice or training in entrepreneurship.

The directors each received a list of all business owners in their region. They were instructed to select fifteen typical successful entrepreneurs and fifteen typical 
successful small business owners, for whom they unanimously used the term "hosts". This differentiation was based on the definitions of the small business owner by Carland et al. (1984), and the definition of income-substituting low-growth potential business owner of Kunkel (2001). Discriminatory criteria were predominantly profitability and growth of the venture, but also on entrepreneurial orientation versus "hospitality" or customer orientation of the business owner. Both groups were "successful" in the sense that they were financially healthy, and were not experiencing financial problems (cf. Cooper, Gimeno-Gascon, \& Woo, 1994). In total, 480 successful business owners were identified, 194 of which participated ( 83 entrepreneurs and 111 small business owners; response-rate $=40.4 \%$ ). Participants were 80.4 percent male and 18.6 percent female. Average age of the participants was 42.9 years $(\mathrm{SD}=$ 9.1). All subjects had owned a café or restaurant in The Netherlands for on average 10.3 years $(\mathrm{SD}=8.1)$.

As a validation of the two groups distinguished by the subject matter experts, we tested they indeed differed significantly on typical organizational and demographic background variables. The findings support the categorization. A larger percentage of entrepreneurs had established their ventures as compared to small business owners $(\mathrm{F}(1,192)=16.99, p<.01)$. About 64 percent of the entrepreneurs had growth ambitions such as opening a second establishment or extending their current venture, whereas only 43 percent of small business owners had this ambition $(\mathrm{F}(1,192)=8.42, p$ $<$.01). Subsequently, concerning the characteristics of the venture, results showed that the average profit of the entrepreneurs was higher than the average profit of the small business owners $(\mathrm{F}(1,192)=15.99, p<.01)$. In addition, entrepreneurs demonstrated higher growth rates. The profits of the entrepreneurs increased significantly more than did the profits of the small business owners $(\mathrm{F}(1,192)=5.15, p<.05)$. Furthermore, 
results demonstrate that on average, entrepreneurs employed more people than small business owners $(\mathrm{F}(1,192)=5.91, \mathrm{p}<.05)$. No differences were found concerning the demographic factors age, gender, and education $(F(1,192)=2.22$, n.s.; $F(1,192)=.51$, n.s. and $F(1,192)=2.61$, n.s. respectively).

\section{Instrumentation}

The on-line questionnaire included 22 items measuring traits and competencies, and a number of questions regarding demographic information of the entrepreneur and the venture (see Appendix 1). Each of the seven characteristics and competencies were measured with multi-item five-point Likert scales. Subjects rated the extent to which they agreed with propositions. All scales contained the following response options: $1=$ "strongly disagree", 2="moderately disagree", 3="neither agree nor disagree", 4= "moderately agree", and 5="strongly agree".

Independence and risk-taking propensity were each measured with three-items developed by Van den Brink, koch, Ardts \& Van Lankveld (2004). Example items are: "I judge situations independently" (independence), and "If I get a chance I take it, even if the consequences can be profound" (risk taking). Cronbach's $\alpha$ of these scales were .70 and .80 respectively.

Tolerance of ambiguity was measured with two items from the Self-Regulatory Control Scale by Cantwell \& Moore (1996), for example "I perceive a vague and uncertain situation as a challenge, rather than a threat." Crohnbach's $\alpha=.69$.

Self-efficacy was assessed by a shortened version of the Occupational SelfEfficacy Scale (OCCSEEF) by Schyns and Von Collani (2002). One example is "I am confident that I could deal efficiently with unexpected events in my job." Cronbach's $\alpha$ was .74. 
To measure the degree of innovativeness and creative abilities, a three-item scale was composed based on items from the Values in Action Scale (Peterson \& Seligman, 2004) and the HEXACO Personality Inventory (Lee \& Ashton, 2004). Typical items in this scale are "I am well known for my innovative ideas" and "I consider creativity to be one of my stronger points." Cronbach's $\alpha$ was .78.

Market orientation was measured with three items obtained from Han, Kim and Srivastava (1998), and Li \& Cantalone (1998), for example: "My knowledge of customer needs is thorough and I use this information to attract new customers". Cronbach's $\alpha$ was .74.

Leadership Qualities were measured by a five-item scale developed by the authors for the purpose of the current study, for example "I stimulate my employees to cooperate" and "I regularly provide feedback to my employees about their functioning." Cronbachs' $\alpha$ was .86 .

\section{Results}

To compare entrepreneurs and successful small business owners on their personality characteristics and competencies, an overall multivariate analysis of variance (MANOVA) was calculated. Afterwards, a univariate analysis of variance (ANOVA) was used to assess the exact differences between entrepreneurs and small business owners on each of the scales. An ANOVA was also used to analyze the differences between the groups on the background variables regarding the entrepreneur and its venture. Next, we analyzed group differences on the seven characteristics and competencies with a MANOVA. Results are shown in Table 1. The intercorrelations among the seven scales are shown in Table 2.

The data-analysis showed a significant group-effect with Wilks' Lambda $=.90$, $F(1,186)=3.06, p<.01$. This indicates a group difference between entrepreneurs and 
small business owners. Subsequently, ANOVAs were performed to assess on which variables the two groups differed.

Insert Table 1 about here

Significant differences between entrepreneurs and small business owners were found on five of the seven scales measuring traits and competencies. Entrepreneurs demonstrated significantly higher levels of independence than did small business owners, which is in line with the first hypothesis; $F(1,192)=4.92, p<.05$. In line with Hypothesis 2, entrepreneurs also had higher risk-taking propensities than small business owners did. Also, entrepreneurs manifested significantly higher levels of tolerance of ambiguity than small business owners. This result is in line with the assumption as stated in the third hypothesis. Analysis confirmed that entrepreneurs displayed higher levels of innovativeness and creativity as compared to small business owners, which confirms Hypothesis 5. The final significant result was found on leadership qualities. In line with the seventh hypothesis, entrepreneurs demonstrated significantly higher leadership qualities than small business owners. Neither self-efficacy nor market orientation significantly differentiated between entrepreneurs and small business owners. Consequently, hypotheses four and six were not confirmed.

Insert Table 2 about here

\section{Discussion and conclusions}

This study tested seven hypotheses on competencies and traits that would differentiate entrepreneurs from small business owners in the hospitality industry. Our expectations were based on process definitions of entrepreneurship and small business owners (Carland et al., 1984; Kunkel, 2001; Shane et al., 2003); comprising entrepreneurial versus small business goals; and entrepreneurial activities that require 
independent thinking and creativity which are performed in ambiguous, uncertain and unstable situations (Scheré, 1982; Begley \& Boyd, 1987b; Koh, 1996).

Our findings coincide with differences in goals of entrepreneurs and small business owners. Entrepreneurs exhibit the psychological profile that is consistent with innovation, growth and profit, combined with the capacity to motivate other people. Small business owners display lower levels of characteristics and competencies that enable people to tolerate and create novel situations, hence they may be more attuned to stability. First, consistent with our hypotheses, the results of this study illustrate that entrepreneurs had a higher level of independence, defined as relying on one's own judgments, than small business owners did. Second, entrepreneurs displayed higher ambiguity tolerance than small business owners did. The same holds true for the third characteristic, risk-taking propensity, defined as taking calculated risks in order to obtain identifiable gains, which is considered inherent to entrepreneurship and has often been associated with entrepreneurial individuals (Shane et al., 2003; Carland et al., 1984). Fourth, consistent with recent findings (e.g. Wart, 2004; Bartram, 2005), entrepreneurs in this study rated themselves as more creative than small business owners. These results line up with findings from Stewart et al. (1998), who portrayed entrepreneurs as "driven, creative risk-takers" with high achievement motivation, a higher propensity for risks and preference for innovation as compared to small business owners.

Our results contrast with those from several other studies showing that entrepreneurs are less risk-oriented than people in other populations. The definition of the focus sample of entrepreneurs and the comparison groups used may be crucial explaining such findings. For example, differences between business founders and nonfounders could be obscured if researchers do not take into account the goals of the 
business founder, such as innovation and growth ambition. This means that the group of business founders can also contain future small business owners.

The fifth and last variable on which a significant difference between entrepreneurs and small business owners was found concerns leadership qualities. Prior studies revealed the link between entrepreneurial success and leadership (Timmons, 1990; Hornaday \& Aboud, 1971). The difference between entrepreneurs and small business owners on this competence has not been investigated before. Based on assumptions on leadership and entrepreneurship in general, we expected that entrepreneurs would score higher on leadership qualities. The results confirmed this expectation and illustrated that entrepreneurs obtain a significantly higher score than small business owners on a scale measuring leadership competencies.

Contrary to the expectations, no significant differences between entrepreneurs and small business owners were found concerning self-efficacy and market-orientation. Entrepreneurs and small business owners both scored relatively high on self-efficacy. However, it is possible that entrepreneurs and small business owners use these competencies in a different manner. Self-efficacy has been associated with typical entrepreneurial business characteristics, such as venture growth (Baum \& Locke, 2004; Markman \& Baron, 2003). Likewise, market-orientation was expected to be a prerequisite for developing new business ideas. However, for small business owners self-efficacy and market orientation may perhaps relate to other criteria, such as customer satisfaction. They may use the information to improve their services within the boundaries of what they were already doing. Possibly other variables, such risktaking propensity, creativity or achievement motivation, moderate the relation between market-orientation and entrepreneurial activities, specifically growing and innovating.

A unique feature of this study is that subject matter experts had identified 
entrepreneurs and successful small business owners in the hospitality industry. This procedure is quite common in work and organizational psychology, where, for example, supervisors and co-workers often indicate workers' job performance (Murphy \& Cleveland, 1995). An advantage of this approach is that it is more holistic. This is important, because many external factors play a crucial role predicting entrepreneurial status, actions and performance, plus there are many characteristics by which one can define entrepreneurs. Analysis of the background variables showed that significant differences were indeed found on all of these variables on group level. For example, entrepreneurs had higher profits, had more employees, and their ventures had more often grown in the last year compared to the small businesses. Additionally, entrepreneurs had more ambitions to open a second establishment or to expand their current venture than small business owners. Had we wanted to create groups based on all these variables without inside information, we would have been faced with many difficulties and questions. For example, we might have decided that all people with plans to expand the establishment are entrepreneurs, even though small business owners may also have plans to expand, be it less often and for other reasons.

\section{Limitations and Suggestions for Further Research}

The merits of this study are the combination of in-debt qualitative insights from subject matter experts, who identified entrepreneurs and small business owners, and a quantitative survey study among a large and homogenous sample. However, it also has several limitations inherent to a concomitant reliance on cross-sectional, self-report data. Respondents tend to evaluate themselves slightly too positive on competency scales (Morgeson, Delaney-Klinger, Mayfield, Ferrara \& Campion, 2004). However, this response biases can be expected to occur for both entrepreneurs and small business owners, so it may have posed a relatively small threat to our results concerning group 
differences.

Because most of the characteristics we studied are quite stable, we assumed that possessing these characteristics and traits leads to selection of certain individuals into entrepreneurship, and of people not possessing these characteristics into other forms of self-employment. However, the cross-sectional design of our study does not allow conclusions concerning causality of relationships. Future research could use longitudinal designs in which entrepreneurs and small business owners are followed from the venture start-up until the enterprise is self-sustaining, and investigate whether certain competencies or personality characteristics had been present from the start, or have developed over time.

Third, the main focus of this study was to identify significant personality constructs and competencies on which entrepreneurs and small business owners can be distinguished. The psychological antecedents were only implicitly linked with possible entrepreneurial behavior and goals, such as growth and profit. Future research could focus more explicitly on the link between personal characteristics, and specific goals and behaviors of entrepreneurs and small business owners. A specific example may be a positive attitude towards, and being knowledgeable and skillful in the field of modern HRM practices. Engaging in HRM practices has been shown to predict business growth (cf. Urbano \& Yordanova, 2008). In addition, it could be investigated whether certain individual characteristics predict successful engagement in specific entrepreneurial activities, such as whether self-efficacy and risk aversion might predict gestation activities (cf. Menzies, Diochon, Gasse \& Elgie, 2006), whether innovativeness might predict attracting and maintaining customers, and whether independence might stimulate defending individual positions within the globalizing tourism industry (Guzman, Moreno \& Tejada, 2008). For small business owners, goals would need to be 
formulated more in terms of what they do strive for (e.g., stability, costumer satisfaction), rather than what they do not strive for as compared to entrepreneurs.

In addition, more attention could be paid to environmental factors on a more aggregate level that might influence the business, and which could possibly moderate relationships between individual characteristics and firm performance. Examples of such factors are market dynamics (Carree, Santarelli \& Verheul, 2008), but also the relative independence of one type of business owner as compared to another type. Previous studies have, for example, shown that starting franchise entrepreneurs are less experienced, and have less confidence in their skills than other nascent entrepreneurs. However, because they can use an already established business model and can get support from the franchiser (Sardy \& Alon, 2007), this may pose a smaller threat to their business success.

\section{To Conclude}

Researchers have emphasized the need for a framework that aggregates individual differences into business owners' competencies and gives clarity and insights that support decision making of (future) business owners, potential investors, buyers and partners (Markman, 2007). Our study contributes to refinement of a taxonomy of business owners, and is useful in more fully understanding business owners of all types. The results of this study indicate that it is crucial to carefully define the group of interest, or "the business owner" and the comparison groups based on their goals and orientation, in order to be able to draw relevant conclusions.

Concerning practical implications, results of our study can be used for selection and training of small business owners into more entrepreneurial ways of running a business in the hospitality industry. Running a small business can be a legitimate choice. However, recent studies have indicated that the slower growth rates of small 
businesses can lead to insufficient returns on personal investments (time and effort) in terms of growth in other areas (number of customers, sales and profit), causing a slow bleed of personal energy and confidence in the future of the owner manager (Welbourne, 2006). On the other hand, potential partners and investors need to be cautious that assessments of entrepreneurial characteristics may be effective in differentiating entrepreneurs from small business owners, but may not identify potentially successful entrepreneurs from those who have a high chance of businessfailure. For that purpose it may be safer to rely on good understanding of opportunities and objective business characteristics that are exemplary of business success in the past than on individual characteristics of entrepreneurs. 


\section{References}

Ahmed, S.U. (1985). nAch, risk-taking propensity, locus of control and entrepreneurship. Personality and Individual Differences, 6, 781-782.

Aldridge, J.H., Jr. (1997). An occupational personality profile of the male entrepreneur as assessed by the 16PF fifth edition. Unpublished doctorial dissertation, University of Georgia.

Altinay, L. and E. Altinay (2006). "Determinants of ethnic minority entrepreneurial growth in the catering sector." Service Industries Journal 26(2): 203-221.

Altink, W.M.M., \& Born, M.Ph. (1993). Prediction of entrepreneurial success: The development of a rating scale for entrepreneurial characteristics. International Journal of Selection and Assessment, 1, 95-106.

Babb, E.M., \& Babb, S.V. (1992). Psychological traits of rural entrepreneurs. The Journal of Socio-Economics, 21, 353-362.

Bandura, A. (1997). Self-efficacy: The exercise of self control. New York: Freeman.

Baron, R.A., \& Markman, G.D. (2003). Beyond social capital: The role of entrepreneurs' socials competence in their financial success. Journal of Business Venturing, 18, 41-60.

Bartram, D. (2005). The great eight competencies: A criterion-centric approach to validation. Journal of Applied Psychology, 90, 1185-1203.

Baum, J.R., Frese M., \& Baron, R.A. (2007). The psychology of entrepreneurship. London: Lawrence Erlbaum Associates.

Baum, J.R., \& Locke, E.A. (2004). The relationship of entrepreneurial trails, skill, and motivation to subsequent venture growth. Journal of Applied Psychology, 89, 587598.

Begley, T.M. (1995). Using founder status, age of firm, and company growth rate as the 
basis for distinguishing entrepreneurs from managers of smaller businesses. Journal of Business Venturing, 10, 249-263.

Begley, T.M., \& Boyd, D.P. (1987a). A comparison of entrepreneurs and managers of small business firms. Journal of Management, 13, 99-108.

Begley, T.M., \& Boyd, D.P. (1987b). Psychological characteristics associated with performance in entrepreneurial firms and smaller businesses. Journal of Business Venturing, 2, 79-91.

Brandstätter, H. (1997). Becoming an entrepreneur - a question of personality structure? Journal of Economic Psychology, 18, 157-177.

Bryson, J., D. Keeble, and Wood (1993). "The Creation, Location and Growth of Small Business Service Firms in the United-Kingdom." Service Industries Journal 13(2): $118-131$.

Budner, S. (1962). Intolerance of ambiguity as a personality variable. Journal of Personality, 30, 29-50.

Busenitz, L.W., \& Barney, J.B. (1997). Differences between entrepreneurs and managers in large organizations: Biases and heuristics in strategic decision-making. Journal of Business Venturing, 12, 9-30.

Cantwell, R.H., \& Moore, P.J. (1996). The development of measures of individual differences in self-regulatory control and their relationship to academic performance. Contemporary Educational Psychology, 21, 500-518.

Carree, M., Santarelli, E., \& Verheul, I. (2008). Firm entry and exit in Italian provinces and the relationship with unemployment. International Entrepreneurship and Management Journal, 4, 171-186.

Carland, J.W., Hoy, F., Boulton, W.R., \& Carland, J.A.C. (1984). Differentiating entrepreneurs from small business owners: A conceptualization. Academy of 
Management Review, 9, 354-359.

Carland, J.W., Hoy, F., \& Carland, J.A.C. (1988). "Who is an entrepreneur?" Is a question worth asking. American Journal of Small Business, 12, 33-39.

Carton, R.B., Hofer, C.W., \& Meeks, M.D. (1998). The entrepreneur and entrepreneurship: Operational definitions of their role in society. Paper presented at the annual International Council for Small Business Conference, Singapore.

Chen, C.C., Greene, P.G., \& Crick, A. (1998). Does entrepreneurial self-efficacy distinguish entrepreneurs from managers? Journal of Business Venturing, 13, 295316.

Cooper, A. C., Gimeno-Gascon, F., \& Woo, C. Y. (1994). Initial human and financial capital as predictors of new venture performance. Journal of Business Venturing, 9, 371-395.

Cromie, S. (2000). Assessing entrepreneurial inclinations: Some approaches and empirical evidence. European Journal of Work and Organizational Psychology, 9, 7-30.

Dobon, S. R. and D. R. Soriano (2008). Exploring alternative approaches in service industries: the role of entrepreneurship. The Service Industries Journal, 28(7): 1-6.

Drucker, P.F. (1985). Innovation and Entrepreneurship. New York: Harper and Row.

Duchesneau, D.A., \& Gartner, W.B. (1990). A profile of new venture success and failure in an emerging industry. Journal of Business Venturing, 5, 297-312.

Feist, J., \& Feist, G.J. (2006). Theories of personality; $6^{\text {th }}$ edition. New York: McGraw - Hill.

Gorgievski, M.J. \& Zarafshani, K. (2008). Entrepreneurial Success, a Values Approach. In: Moriano-Leon, J.A., Gorgievski, M.J. \& Lukeš, M. (eds.) Psychology of Entrepreneurship (pp. 135-158), Madrid: Uned 
Guzmán, J., Moreno, P., \& Tejada, P. (2008). The tourism SMEs in the global value chains: The case of Andalusia. Service Business, 2, 187-202.

Han, J.K., Kim, N., \& Srivastava, R.K. (1998). Market orientation and organization performance: Is innovation a missing link? Journal of Marketing, 62, 30-45.

Hisrich, R.D. (1990). Entrepreneurship/Intrapreneurship. American Psychologist, 45, 209-222.

Hornaday, J. A., \& Aboud, J. (1971). Characteristics of successful entrepreneurs. Personnel Psychology, 24, 141-153.

House, R. J. (2004). Culture, Leadership, and Organizations: The GLOBE Study of 62 Societies, Thousand Oaks: SAGE Publications.

Kaish, S., \& Gilad, B. (1991). Characteristics of opportunities search of entrepreneurs versus executives: Sources, interests, general alertness. Journal of Business Venturing, 6, 45-61.

Koh, H.C. (1996). Testing hypotheses of entrepreneurial characteristics : A study of Hong Kong MBA students. Journal of Managerial Psychology, 11, 12-25.

Kunkel, S. W. (2001). Toward a typology of entrepreneurial activities. Academy of Entrepreneurship Journal, 7, (1) 75-90.

Kuratko, D. F., Hornsby, J. S., \& Naffziger, D. W. (1997). An Examination of owners' Goals in Sustaining Entrepreneurship. Journal of Small Business Management, 35 (1), 24.

Lee, K., \& Ashton, M.C. (2004). Psychometric properties of the HEXACP personality inventory. Multivariate Behavioral Research, 39, 329-358.

Li, T., \& Calantone, R.J. (1998). The impact of market knowledge competence on new product advantage: Conceptualization and empirical examination. Journal of Marketing, 62, 13-29. 
Lim, S., D. Ribeiro, \& S.M. Lee. (2008). "Factors affecting the performance of entrepreneurial service firms." The Service Industries Journal, 28(7).

Lumpkin, G.T. \& Dess, G.G. (1996). Clarifying the entrepreneurial orientation construct and linking it to performance. Academy of Management Review, 21, 135172.

MacDonald, A.P., Jr. (1970). Revised scale for ambiguity tolerance: Reliability and validity.

Markman, G.D. (2007). Entrepreneurs' competencies. In J.R. Baum, M. Frese., \& R.A. Baron (Eds.), The psychology of entrepreneurship. London: Lawrence Erlbaum Associates, 67-92.

Markman, G.D., \& Baron, R.A. (2003). Person-entrepreneurship fit: Why some people are more successful as entrepreneurs than others. Human Resource Management Review, 13, 281-301.

Mazzarol, T., \& Reboud, S. (2006). The strategic decision making of entrepreneurs within small high innovator firms. International Entrepreneurship and Management Journal, 2, 261-280.

Menzies, T. V., Diochon, M., Gasse, Y., \& Elgie, S. (2006). A longitudinal study of the characteristics, business creation process and outcome differences of Canadian female vs. male nascent entrepreneurs. International Entrepreneurship and Management Journal, 2, 441-453.

Morgan, R.E., \& Strong, C.A. (1998). Market orientation and dimensions of strategic orientation. European Journal of Marketing, 32, 1051-1073.

Morgeson, F.P., Delany-Klinger, K., Mayfield, M.S., Ferrara, P., \& Campion, M.A. (2004). Self-presentations processes in job analysis: A field experiment investigating inflation in abilities, tasks, and competencies. Journal of Applied 
Psychology, 89, 674-686.

Murphy, K.R. \& Cleveland, J.N. (1995). Understanding performance appraisal: social, organisational and goal based perspectives. Thousand Oaks, CA: Sage

Peterson, C., \& Seligman, M.E.P. (2004). Character strengths and virtues: A handbook and classification. Oxford University Press: Oxford.

Pines, A.M., Sadeh, A., Dvir, D., \& Yafe-Yanai, O. (2002). Entrepreneurs and managers: Similar yet different. The International Journal of Organizational Analysis, 10, 172-190.

Rauch, A. \& Frese, M. (2000). Psychological approaches to entrepreneurial success: A general model and an overview of findings. In C.L. Cooper \& I.T. Robertson (Eds.), International Review of Industrial and Organizational Psychology. Chichester: Wiley, 101-142.

Rauch, A., \& Frese, M. (2007a). Born to be an entrepreneur? Revisiting the personality approach to entrepreneurship. In J. R. Baum, Frese, M., Baron, R. (Ed.), The Psychology of Entrepreneurship. London, GB: Lawrence Earlbaum Associates.

Rauch, A., \& Frese, M. (2007b). Let's put the person back into entrepreneurship research: A meta analysis on the relationship between business owners' personality traits, business creation and success. European Journal of Work and Organizational Psychology, 16, 353-385.

Sardy, M., \& Alon, I. (2007). Exploring the differences between franchisee entrepreneurs and nascent entrepreneurs. International Entrepreneurship and Management Journal, 3, 403-418.

Scheré, J. (1982). Tolerance of ambiguity as a discriminating variable between entrepreneurs and managers. Academy of Management Best Paper Proceedings, 42, 404-408. 
Schneider, B., Goldstein, H.W., Smith, D.B. (1995) The ASA framework, an update, Personnel psychology, 48, 747-773.

Schumpeter, J.A. (1934). The theory of economic development: An inquiry into profits, capital, credit, interest, and the business cycle. Cambridge, MA: Harvard University Press.

Schyns, B., \& Von Collani, G. (2002). A new occupational self-efficacy scale and its relation to personality constructs and organizational variables. European Journal of Work and Organizational Psychology, 11, 219-241.

Shane, S., Locke, E.A., \& Collins, C.J. (2003). Entrepreneurial motivation. Human Resource Management Review, 13, 257-279.

Smid, N., \& Van der Woude, M. (2005). Coachen op gedrag en resultaat. Praktijkgids voor het ontwikkelen van resultaatgericht gedrag. PiMedia, Utrecht.

Smith, N. R., \& Miner, J. B. (1983). Type of entrepreneur, type of firm, and managerial motivation: Implications for organisational life cycle theory. Strategic Management Journal, 4, 325-340.

Stewart, W.H., Jr., Watson, W.E., Carland, J.A.C., \& Carland, J.W. (1998). A proclivity for entrepreneurship: A comparison of entrepreneurs, small business owners, and corporate managers. Journal of Business Venturing, 14, 189-214.

Tang, J., Tang, Z., \& Lohrke, F. T. (2008). Developing an entrepreneurial typology: The roles of entrepreneurial alertness and attributional style. International Entrepreneurship and Management Journal, 4, 273-294.

Timmons, J.A. (1990). New Venture Creation. Homewood, IL: Irwin.

Urbano, D., \& Yordanova, D. (2008). Determinants of the adoption of HRM practices in tourism SMEs in Spain: An exploratory study. Service Business, 2, 167-185.

Utsch, A., Rauch, A., Rothfuss, R., \& Frese, M. (1999). Who becomes a small scale 
entrepreneur in a post-socialist environment: On the differences between entrepreneurs and managers in East Germany. Journal of Small Business Management, 37, 31-42.

Van den Brink, F., Koch, B., Ardts, J. Van Lankveld, J. (2004) Wat heeft de Kramer in zijn mars? De rol van persoonlijkheidskenmerken bij verschillende typen ondernemerschap. Tilburg, The Netherlands: GITP.

Venkataraman, S. (1997). The distinctive domain of entrepreneurship research: An editor's perspective. In J. Katz \& J. Brockhaus (Eds.), Advances in Entrepreneurship, Firm Emergence and Growth. Greenwich, CT: JAI Press.

Ward, T.B. (2004). Cognition, creativity, and entrepreneurship. Journal of Business Venturing, 19, 173-188.

Welbourne, T. M. (2006). Learning about leadership and firm growth through monthly data collection and dialogue with entrepreneurs. International Entrepreneurship and Management Journal, 2, 39-55.

White, R.E., Thornhill, S., \& Hampson, E. (2006). Entrepreneurs and evolutionary biology: The relationship between testosterone and new venture creation. Organizational Behavior and Human Decision Processes, 100, 21-34.

Zhao, H., \& Seibert, S.E., \& Hills, G.E. (2005). The mediating role of self-efficacy in the development of entrepreneurial intentions. Journal of Applied Psychology, 90, 1265-1272. 
Table 1. Group differences in characteristics and competencies of 83 entrepreneurs and 111 small business owners

Entrepreneurs $\quad$ Small Business Owners

\begin{tabular}{llllll} 
& $\mathrm{M}$ & $\mathrm{SD}$ & $\mathrm{M}$ & $\mathrm{SD}$ & $\mathrm{F}$ \\
\hline Independence & 3.74 & .67 & 3.50 & .80 & $4.92^{*}$ \\
Risk-taking propensity & 3.71 & .74 & 3.46 & .71 & $5.97^{*}$ \\
Tolerance of ambiguity & 3.79 & .69 & 3.53 & .68 & $7.04^{* *}$ \\
Self-efficacy & 4.11 & .41 & 4.02 & .52 & 1.59 \\
Innovativeness & 3.95 & .63 & 3.65 & .56 & $12.48^{* *}$ \\
Market orientation & 4.10 & .46 & 4.00 & .57 & 1.73 \\
Leadership competencies & 4.18 & .50 & 3.99 & .54 & $6.22^{*}$ \\
\hline \hline
\end{tabular}

Note: $* p<.10$ (1-tailed); $* * p<.05$ (1-tailed); 
Table 2. Means, Standard deviations and Correlation coefficients among personality characteristics and competencies.

$\begin{array}{lllllllll}\text { Mean } & S D & 1 & 2 & 3 & 4 & 5 & 6 & 7\end{array}$

1. Independence $\quad 3.60 \quad .75 \quad \mathbf{7 0}$

2. Risk-taking propensity $\quad 3.57 \quad .73 \quad .26 * * \quad .80$

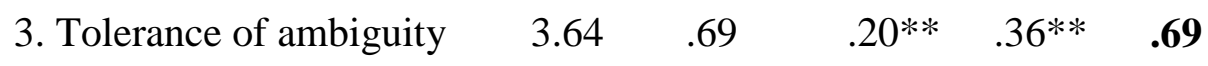

$\begin{array}{llllllll}\text { 4. Self-efficacy } & 4.06 & .48 & .11 & .23 * * & .43^{* *} & .74\end{array}$

$\begin{array}{lllllllll}5 . \text { Innovativeness } & 3.78 & .61 & .12 & .50^{* *} & .33^{* *} & .36^{* *} & \mathbf{. 7 8}\end{array}$

$\begin{array}{lllllllll}\text { 6. Market orientation } & 4.04 & .53 & .03 & .30 * * & .31 * * & .51 * * & .46 * * & \mathbf{7 4}\end{array}$

$\begin{array}{llllllllll}\text { 7. Leadership competencies } & 4.07 & .53 & -.01 & .17 * * & .22 * * & .30 * * & .28 * * & .37 * * & \mathbf{8 6}\end{array}$

Note: The internal reliabilities of the scales are displayed on the diagonal of the table. $* p<.05 ; * * p$ $<.01$. 
Appendix 1. Competencies and Personality Items

Independence (Van den Brink et al., $2004 ; \alpha=.70$ )

1. I prefer to make decisions by myself

2. I judge independently, even if others don't agree with me.

3. Even under pressure I make my own decisions.

Risk-Taking propensity (Van den Brink et al., 2004; $\alpha=.80$ )

1. I regularly take calculated risks in order to obtain potential advantage.

2. If I get a chance I take it, even if the consequences can be profound.

3. I'm prepared to invest much of my own capital to take a chance.

Tolerance of ambiguity (Cantwell \& Moore, 1996; $\alpha=.69$ )

1. I perceive a vague and uncertain situation as a challenge, rather than a threat.

2. It is not unusual for me to change the way I am working if the situation requires change

Self-efficacy (OCCSEFF-scale Schyns \& Collani, 2002; $\alpha=.74$ )

1. When I am confronted with a problem, I can usually find several solutions.

2. I am confident that I could deal efficiently with unexpected events in my job.

3. No matter what comes my way, I' usually able to handle it.

Innovativeness $(\alpha=.78)$

1. I consider creativity as one of my stronger points.

2. I am open for new and special ideas.

3. People often are impressed by my renewing ideas.

Market Orientation (Li \& Cantalone, 1998; $\alpha=.74$ )

1. I closely monitor and assess our level of commitment in serving customers' needs.

2. My knowledge of customer needs is thorough and I use this information to attract new customers.

3. I know how to make sure that my customers will return to my venture.

Leadership Qualities (Composed by authors; $\alpha=.86$ )

1. I stimulate my employees to cooperate.

2. My employees don't mind doing extra tasks if I ask them to.

3. I stand close to my employees.

4. I regularly provide feedback to my employees about their functioning.

5. I motivate my employees in order to keep them enthusiastic. 


\section{Publications in the ERIM Report Series Research* in Management}

\section{ERIM Research Program: "Organizing for Performance"}

2008

Explaining Preferences and Actual Involvement in Self-Employment: New Insights into the Role of Gender Ingrid Verheul, Roy Thurik and Isabel Grilo ERS-2008-003-ORG

http://hdl.handle.net/1765/10979

Public Finance in China since the Late Qing Dynasty

Barbara Krug

ERS-2008-005-ORG

http://hdl.handle.net/1765/11287

Overoptimism among Founders: The Role of Information and Motivation

Ingrid Verheul and Martin Carree

ERS-2008-008-ORG

http://hdl.handle.net/1765/11557

Do Foreign Greenfields Outperform Foreign Acquisitions or Vice Versa? An Institutional Perspective Arjen H.L. Slangen and Jean-François Hennart ERS-2008-009-ORG

http://hdl.handle.net/1765/11558

Unemployment Benefits Crowd Out Nascent Entrepreneurial Activity

Philipp Koellinger and Maria Minniti

ERS-2008-012-ORG

http://hdl.handle.net/1765/11808

Acceleration of Technology Adoption within Firms: Empirical Evidence from the Diffusion of E-business Technologies Philipp Koellinger and Christian Schade

ERS-2008-013-ORG

http://hdl.handle.net/1765/11809

Belbin Revisited: The Construct Validity of the Interplace II Team Role Instrument

Dirk van Dierendonck and Rob Groen

ERS-2008-017-ORG

http://hdl.handle.net/1765/12123

China's Institutional Architecture: A New Institutional Economics and Organization Theory Perspective on the Links between Local Governance and Local Enterprises

Barbara Krug and Hans Hendrischke

ERS-2008-018-ORG

http://hdl.handle.net/1765/12191

Ethics Programs and Ethical Cultures: A Next Step in Unraveling their Multi-Faceted Relationship

Muel Kaptein

ERS-2008-020-ORG

http://hdl.handle.net/1765/12192

Entrepreneurship Education and Training in a Small Business Context: Insights from the Competence-based Approach Thomas Lans, Wim Hulsink, Herman Baert and Martin Mulder

ERS-2008-028-ORG

http://hdl.handle.net/1765/12466 
The Relationship between Technology, Innovation, and Firm Performance: Empirical Evidence on E-Business in Europe Philipp Koellinger

ERS-2008-031-ORG

http://hdl.handle.net/1765/12469

The Relationship between Ethical Culture and Unethical Behavior in Work Groups: Testing the Corporate Ethical Virtues Model

Muel Kaptein

ERS-2008-037-ORG

http://hdl.handle.net/1765/12783

Influence Costs in Agribusiness Cooperatives: Evidence from Case Studies

Constantine Iliopoulos and George Hendrikse

ERS-2008-040-ORG

http://hdl.handle.net/1765/12872

The Locus of Innovation in Small and Medium-sized Firms: The Importance of Social Capital and Networking in Innovative Entrepreneurship

Willem Hulsink, Tom Elfring and Wouter Stam

ERS-2008-041-ORG

http://hdl.handle.net/1765/12873

Stimulating Strategically Aligned Behaviour among Employees

Cees B. M. van Riel, Guido Berens and Majorie Dijkstra

ERS-2008-045-ORG

http://hdl.handle.net/1765/12903

Creating Strategic Aligned Behavior among Employees at Philips

Cees B.M. van Riel and Guido Berens

ERS-2008-046-ORG

http://hdl.handle.net/1765/13218

Why Identify? Self-Enhancement and Self-Consistency Motives in Organizational Identification

Mirdita N. Elstak, Cees B.M. van Riel and Michael G. Pratt

ERS-2008-047-ORG

http://hdl.handle.net/1765/13219

Science and Technology-based Regional Entrepreneurship in the Netherlands: Building Support Structures for Business

Creation and Growth Entrepreneurship

Willem Hulsink, Kashifa Suddle and Jolanda Hessels

ERS-2008-048-ORG

http://hdl.handle.net/1765/13220

I Can't Get No Satisfaction - Necessity Entrepreneurship and Procedural Utility

Joern Block and Philipp Koellinger

ERS-2008-051-ORG

http://hdl.handle.net/1765/13221

Financial Geographies and Emerging Markets in Europe

Bas Karreman

ERS-2008-054-ORG

http://hdl.handle.net/1765/13222

Entrepreneurship, Economic Growth and Policy in Emerging Economies

Roy Thurik

ERS-2008-060-ORG

http://hdl.handle.net/1765/13318 
License to Fail? How Leader Group Prototypicality Moderates the Effects of Leader Performance on Perceptions of Leadership Effectiveness

Steffen R. Giessner, Daan van Knippenberg, and Ed Sleebos

ERS-2008-066-ORG

http://hdl.handle.net/1765/13626

The Effect of Legal Families on the Development of Business Law in China: Who's Really Writing the Rules of the Game? Barbara Krug and Nathan Betancourt

ERS-2008-068-ORG

http://hdl.handle.net/1765/13764

Market Feedback and Team Commitment in Radical Product Innovation Process

Luca Berchicci and Christopher Tucci

ERS-2008-069-ORG

http://hdl.handle.net/1765/13765

The Strategic Determinants of Tardy Entry: Is Timeliness Next to Godliness?

Luca Berchicci, Andrew King, and Christopher Tucci

ERS-2008-070-ORG

http://hdl.handle.net/1765/13766

Businessman or Host? Individual Differences between Entrepreneurs and Small Business Owners in the Hospitality Industry Stephanie L. Wagener, Marjan J. Gorgievski, and Serge A. Rijsdijk

ERS-2008-073-ORG

http://hdl.handle.net/1765/13832

Understanding a Two-Sided Coin: Antecedents and Consequences of a Decomposed Product Advantage

Serge A. Rijsdijk, Fred Langerak, and Erik Jan Hultink

ERS-2008-074-ORG

http://hdl.handle.net/1765/13833

A Treatise on the Geographical Scale of Agglomeration Externalities and the Modifiable Areal Unit Problem Martijn J. Burger, Frank G. van Oort, and Bert van der Knaap

ERS-2008-076-ORG

http://hdl.handle.net/1765/13834

* A complete overview of the ERIM Report Series Research in Management: https://ep.eur.nl/handle/1765/1

ERIM Research Programs:

LIS Business Processes, Logistics and Information Systems

ORG Organizing for Performance

MKT Marketing

F\&A Finance and Accounting

STR Strategy and Entrepreneurship 